Ciência eNatura, Santa Maria, v. 37 Part 1 2015, p. 379-387

Revista do Centro de Ciências Naturais e Exatas - UFSM

ISSN impressa: 0100-8307 ISSN on-line: 2179-460X

\title{
ciênciaenatura
}

\section{Teaching Methods in Architectural Design Basics}

\author{
Mahmoud Reza Saghafi ${ }^{1}$, Farhang Mozaffar ${ }^{2}$, Seyed Mohsen Moosavi ${ }^{3}$, \\ Noosheen Fathi ${ }^{4}$
}

\begin{abstract}
During its changes, architecture teaching, bump into several concerns from initial academic teaching up to now and it always tolerates some of them permanently. During recent years, many researches went through that actions with regard to the content debate and organizing architectural teaching. In this present article, we best shot to go one-step forward in order to solve one of the problems teacher hit upon through method expression and consideration of teaching method for Architectural Design Basics Courses. Some of these issues for investigation include, which goals nail down Architectural Design Basics Courses in university teaching system in Iran? What are the methods and approaches for teaching these courses? Which factors shall investigated before starting class session? Which factors are effective on learning process? According to methodology, we started to do research through observation and gathering poll of three universities holding three levels of teaching record in architecture (University of Tehran, Marlik Institute of Higher Education and Fakhr Razi Institute of Higher Education), we out -and- out ideas of students and professors of these courses. In addition, through introducing methods to teach architecture lessons which investigated by researchers during recent years, we will put forward for solutions to improve teaching in Architectural Design Basics. In this article, we took advantage from scanning investigation, we applied observation, library study, and questionnaire to congregate information, and we brought off quality analysis through a grounded theory approach. In concordance with investigation results, one of the success factors for Architectural Design Basics is dramatize many practices which fired up by professors through bring into play different teaching methods.
\end{abstract}

Keywords: Architectural Design Basics, Teaching method, Teaching Approaches, Learning Process. 


\section{Introduction}

Architectural teaching dates back to its starting point from teaching while construction of a building and now it set foot in universities and teaching architecture designing in workshops. We are witness for performing many researches for content debate and organizing research teaching during recent years. One of them, which hold by Tehran University for many years, is national symposium for "Architectural Teaching.". Owing to media and promotion of community information level, people swapped their expectations from architecture to meet their desires in designing modern and valuable buildings. Learners' weakness for specialized lessons of the final course and after that weakness of graduates in entrance exam for Building Engineering System is obvious. For good measure, here we touch on to plan selling markets all of which are good example of accepting this weakness by the side of learners themselves.

For providing our audience with a special subject, all of us enjoy from special methods and we remember the first time of performing it when we do everything, we think about the positive points of second performing of that job and its negative points for not implementation of that work. Now suppose that instead of encountering with a teacher having suitable scientific power, you are going to teach a profession or technic or an art like Architectural Design Basics courses for some students gathered with different motivations and ideas.

The main challenge of this present paper is the teaching method suitable for starting lessons of architecture course, which brings about interest and better learning. Of course if we know all suitable conditions for class.

In this writings, we go through quality analyzing of information by a Grounded Theory approach and scanning investigation which uses observation, library studies and questionnaire in order for gathering information. First, we usher in and call attention to the goals of Architectural Design Basics Courses, then we move on toward data investigation through articulate titles for teaching prototypes to teaching models coherent with architecture courses for three universities, which teach architecture, after, that we let fall to problems and teaching of Architectural Design Basics Courses. And at the end of paper, through providing students, professors, architecture producing institutes and those people who face with architecture and its teaching with useful solutions in order to learn and teach Architectural Design Basics Courses.

\section{Objectives of Architectural Design Basics Courses}

Architecture is a kind of creative action aiming to shape human environment in its total perfection and it holds an expanded range for meeting human needs married with environment and nature and verbalizing his emotions and believes.[1]Among teaching program of B.S. in Architecture in the Architecture Faculty of Tehran University, we can find some goals for the Architectural Design Basics Courses. Please refer to table 1. [2]

Table (1): Teaching goals for Architectural Design Basics. [2]

\begin{tabular}{|c|c|c|}
\hline $\begin{array}{l}\text { Main objectives of } \\
\text { Architectural Design } \\
\text { Basics Courses }\end{array}$ & $\begin{array}{l}\text { Title of basic lessons } \\
\text { for studying }\end{array}$ & Teaching goals in each sections \\
\hline \multirow{3}{*}{$\begin{array}{l}\text {-Space imagination } \\
\text {-imagination } \\
\text { reinforcement } \\
\text {-expressional skills } \\
\text {-reinforcement of } \\
\text { creativity power } \\
\text {-promotion of self } \\
\text { confidence }\end{array}$} & Practical geometry & $\begin{array}{l}\text { Acquiring capability to understand and imagine and their changing- familiarity with signs and } \\
\text { contracts to draw plan- professional in tools drawing used to register and transfer several } \\
\text { information related in building }\end{array}$ \\
\hline & $\begin{array}{l}\text { Basics } \\
\text { architecture } \\
\text { designing }\end{array}$ & $\begin{array}{l}\text { Familiarity with fundamental elements forming a building- reinforcement of imagination power } \\
\text { and wisdom of student }\end{array}$ \\
\hline & $\begin{array}{lr}\text { Understanding } & \text { and } \\
\text { expression } & \text { of }\end{array}$ & $\begin{array}{l}\text { Training and reinforcing a searching and meaning finding looking to observe and understand } \\
\text { environment- simple transferring of observations and environmental receptions through words, }\end{array}$ \\
\hline
\end{tabular}




\section{Teaching methods for Architectural Design Basics Courses}

Totally, in the architecture teaching as the creative problem-solving, the designing issue proposes due to smearing and getting involved student with designing process. So important thing in this process is a path which should follow, not a final output. In this regard, cause to importance of how to follow the path by the student as an amateur designer, proposing of designing issue demands some factors that besides defining and clearing the issue, provide the possibility of creative thinking of amateur designer and guide the process of problemsolving in efficient path.

The structure of designing issue consist of factors that determine and distinguish framework of issue and limit indefinable issue. Designing issue that is proposed with a structure which includes flexibility, plasticity, scalability, allow some criteria, with tool abilities, Capabilityof criticism, will end to efficient process of issue solving and teaching architecture as the creative problemsolving.[ 17]

In this part of article, we briefly explain teaching methods that are helpful for basic courses viewpoint of writer:

\section{Showing and performance of practical exercises:}

This method is a kind of practical skill exercise that trainer shows it. Trainer should provide essential equipment before performance of show and as a professional trainer should practice and perform essential skills. (Such as drawing two point perspectives) mostly after that students learn the essential knowledge and theories, will be able to prepare for learning practical skills. Steps for performance of this method are:

1. Preparing step: trainer should exactly determine the target of teaching and already provide essential equipment.

2. Explaining step: explain the way and the reason of doing the task and the interesting part for students is expressing questions that are expected to answer by them at the end of teaching.

3. Demo step: trainers should show the correct method and the steps of them for example they should explain performing steps of watercolor techniques to students.

4. Experiment and evaluation steps: after running steps that mentioned before, trainers should get outcome from learners to know they completely learn this skills or not? And if they did not, solve their problems.[12]

In active learning students involve what they learn, answer the questions, collaborate in discussions and describe things. [26]

\section{Educational media Technology:}

Provide and choosing educational media that are offered by trainers or students use them themselves, need special attentional. Professional media can deliver their messages with the best quality, furthermore they attract interest, attention and motivation of their learners. The main value of this media is:

1. It can reinforce Perception

2. They are interesting and remain in mind

3. They emphasis on basic and main point that should be teach better and highlight them.

According to quiddity and structure of training in Architecture, using this approach in basic lessons is adaptive. A media isn't chosen without considering why and how it should be used. Choosing appliance (or tools which are about architecture) should be done according to manners and facilities of training institute.

Medias play a top-notch role for architecture teaching. Providing specialized pictures is the most solemn part of teaching course and it is feasible to facilitate architecture teaching for learners through different Medias.[13]

\section{Case by case teaching:}

In this type of teaching, students go through analyzing historical or hypothetical case-by-case 
studies including problem solving or making decisions. Kardoos and Smith define "case' for engineering teaching as " a report of engineering activity, event or issue including some fields and complexes which an engineer face with them in reality". It is possible to utilize this approach in architecture workshop lessons. [8]

\section{Scientific manifestation:}

Scientific manifestation approach is a type of teaching method through which the professor splashes the practical usage of one subject to students and he recapitulates that approach through scientific manifestation method. This method is very salubrious and fruitful in order to embellish thorough realization of architecture by learner. As learning the most parts of architecture debates demands the bolstering of imagination power of student, whereupon, it is propitious to take advantage from those methods of architecture teaching which bring about the conditions for visualization.[18]

\section{Professor and Student Method:}

The method of familiarity of professor and student, as the name tells us, is the reading out and second defining of that old method in the framework of cognitive psychology. This method, nowadays, finds its place among reference textbooks of educational psychology. Six aspects as followings provided for Professor and Student Method.

To be example of: Professor shows student how to perform each work with its specific elegance.

Guiding: Professor has supervision over his student when doing his works and gives him advice instantly for gestures, feedbacks and guides.

Support (care): Professor supports and takes care about his student. He has framework and limitation for his support and as student acquires the capability to perform his work independently, professor leaves him alone. Effective support and care of professor needs his high recognition power to know the time for necessary care of student and the amount of this care and support. Surplus support leads in weakness of student self- confidence. Altogether, less support results in failure of student to perform his work. The amount of professor support is in such a way that student works successfully. The first three aspects mostly relates in guiding and helping student to acquire recognition and Meta -recognition skills through a guided and supported observation and experience.

Expression: This aspect of professor and student method is a kind of test. Professor demands his student to elaborate on process and method of performing his work.

Revision: Student encourages to make comparison between his own work and others including professor and to think about and revise his methods. The next two aspects mostly supervise the process of helping student in order for conscious achieving of his problem solving policies.

Scrutiny (self -analyzing): Student cannot be a repetition of his professor and finally shall manifest his own special characters and powers. For that reason, in his relation with student, professor gives him opportunity for selfanalyzing in secure conditions.

The final aspect of goal is encouraging student for self -analyzing and self -constitute to find problems and solutions for them.[11]

\section{Peer Learning Teaching Method:}

This method is based on teaching of pairs. This method besides that helps students to use period's concept in new positions, teaches them how to be responsible of their own learning. The method of teaching to pairs, is a valuable and very sensitive experience for students in a university educational program. This educational method is almost new one. Experiences of students and their conception of what they have learned will influence on traditional methods by using the method of classmate to classmate teaching with approach of lecture and conference.[14]

Peer-learning is a kind of cooperative learning in which student plays the role of instructor. This method defines special responsibility for student to manage the class.[27]

The process of providing for teaching other persons is required high level of cognition skill 
that cause to enhance the learning experience.[28]

\section{Teaching method with creation of the Design Studio:}

The traditional Designing Studio method that has been common from the past, has been based on Learning by Doing Method. In this method, there are between 10 and 12 student for each instructor. Each student usually propose task of designing and mass models, idea and attitude with the professor and all of students in parallel solve a designing issue. Along educational half year, tasks go forward trough single or group corrections and at the end of half year, a judgment group or a professor of course will evaluate and rank the tasks. Totally, we could mention three specific duties for Studio of architectural designing:

a) Education and practice of some skills like drawing and performing

b) Simultaneously education of express and portrait language

c) Education of architectural thinking for solving problems

The method of studio teaching has types that are different from each other in details. These types are:

Type 1: Students sit around a desk with master and discuss about tasks which they do out of atelier time. In this type, master is lecturer and students are almost inactive.

Type 2: in this position, students do their tasks either at the atelier time or out of atelier and each student work on a single desk in atelier and master investigate their tasks. In this type, there is less public discussion.

Type 3: in the atelier, students are divided to some groups and each group is helped by master's guidance. Students are working on their personal desks in atelier and their masters separately visit their tasks and give them necessary guidance. In this method, the student will be familiar with masters' different comments and would follow the proposition along them. In this method, there is no group discussion.

Type 4: in this method, there is a fixed jury for the atelier that is formed from masters of that atelier and several students advance the task by contribution of some of them. At the end, the task will be evaluated by jury.

Type 5: there is a fixed jury for each atelier. Master consider total students' tasks and 2 till 3 and all of atelier students are similar in their passed educational units. In this method, students can advance the task with masters. In this method, we have group discussion around a desk.

Type 6: there is a fixed jury for each atelier. Master consider total students' tasks and 2 till 3 and all of atelier students are not similar in their passed educational units and they are from different years. In this method, students could advance task with whole masters and according to requirement, group discussion will be around a desk.[15]

\section{Free-Hand Drawing Teaching Method:}

Norman kurou, quarter-century ago, prevented fade importance of notes with photo, Sketching, Free-hand drawing in College education about architectural designing and emphasis the importance of designer Creativity improvement process in architecture educations process by using design paper and hand-free design. He mentions personal design papers are inseparable part of architecture educations.

rabertkirkak in (personal design paper is as an educational tools for learners) article said, using design paper and Sketch continuously has caused improvement of learners self-confidence against architect basic lessons. According to him, a short part of design and hand-free sketch Source or architectural sketch can transfer Full backing Perception drawing and designing, perspective and Instructions of colors to learners. So if trainers can teach main and basic necessary theories for hand-free design strategy, it could provide better learning condition for learners. Providing efficient and effector design process, is one of the most important Educational aims, because hand-free design, especially in creating concept and first steps of design process is very valuable for Architectural idea. Suzan race noting that, this architecture training system often focused on (what) should be designed Instead of (how) could design.[ 2]

\section{Findings of Observations and Gathering Polls:}


Result of observations and gathering polls are in order to expressing learners' concerns of their first designing experience in Architectural Design Basics and totally first educations which they have learned of trainer and we can present that lonely and being away of classmates could be memory of thoughts about having rivals of high school period. Of course, in a comparative image between sketching of two students that one shows high school class and the other one shows university class during designing an educational room, it is considered that teamwork is more noticed in high school in comparing with university. Also, this point has been showed itself from questionnaire that interest of students to group action is evaluated average.

In analyzing collected sketching, the point which is shining in all picture is zooming on instructor, according to writer, modern learners missed guidance of former architecture professors. Empty chairs in these sketches shows learners independence for learning, might they want to say, we know everything but we don't know how we can use this knowledge. You can see future plans concern and money between their gaps. The undeniable point is, this Simplicity and aridity of courses in their Memories shows they are not happy and satisfied about facilities of their academy. It's evident for students in all three universities.

Many other course training troubles related to the basic architecture courses among the professors and students in the three universities in the study, as some of the troubles include:

1) Score grade oriented outlook affecting the students' conduct towards the professors,

2) Training and project evaluation bias

3) lack of academic facilities causing the negligence of the new representation approaches and the training tools,

4) enrollment of architecture students as cheap labor and applying the discrepancies as the professors' requirements in respect to the employment in the architecture context, which has caused the architecture students' disinterest on making their minds and practice,

5) The professors try to fade their weakness on the representation of the utilization of the software even at the introduction level,
6) Although the professor teaches and gives exercises and homework, they neglect to require the feedback of the exercises, so the students' motives diminish,

7) The professors appear in the unserious and unimportant status in the class of the basic sciences, in which the role of these courses would fade and the students would lack the strong capability in the next semesters,

8) The lack of the sufficient courses preceding the basic courses, e.g. visual arts, design, photography, volume building, science of colors; as the course groups dissolve and slow down the learning.

\section{Discussion}

Mr. Hojat (Tehran University's professor) in his article (four season of architecture educations- A closer look of architecture raise and fall in Iran) in criticism of new professors, mentions this points:

1. Teaching without instance( there is no method)

2. Masters without devotee( teachers with traditional idea)

3. Studios cut off from the source(no Collectivity is on)

4. Modern trainers teach like postmodern

5. Grey trainers (brought to the knowledge of the periphery)

6. Replacing Researcher instead of designer architect.[ 21]

However, trainers in Iranians culture teach their knowledge to students, moreover they teach good concept before knowledge (refinement) and good deeds for using this knowledge (wisdom).[21]

One of the wrong politics in modern Architects education is increasing quantity instead of quality. So the result is new institutions are uselessness. Despite the high costs for students (learners), there is no suitable facilities for architect in all these institution.

Institutions uselessness reasons:

1. There is no appropriate lesson plans

2. Contents sand inappropriate departments

3. Lack of specific education objectives

4. Unfamiliarity of teacher with proper course standards [4] 
Some part of the inefficient art training in higher education institutes is the negligence and lack of attention of the visual values of the basic visual art courses [22]. Of course, there are many troubles at the high school grades in relation with the academic students proceeded into the universities, which should be contemplated.

"Art does not reproduce the visible; rather, it makes visible." Paul Klee

Humans own the instinctive interest and desire of design since childhood, as the children are good designers and design with complete assurance, while they express whatever they feel via lines and colors. When they grow, the power of rationalization overcomes their feelings, so they design the objects as they appear. Eventually, they tend to learn the principles of designing skills and the objective visualization increases. In order to achieve success, every child is required to look around by curiosity and honesty and think about it similar to a thoughtful man. Too much practice, accurate guidance, precise realism, and speculation on the artists' works in the form of some of the factors afford to reach the completion in the path of art design. Evidently, the learners can pay attention to the design practice as the art trainer lead them through practices and perseverance, so that the learners can achieve the necessary skills, because they will need the skills in the next steps due to their success rate of proposing an artwork, particularly in the context of the visual (architectural) arts, in which the design art skills are determinant.

If a poet begins with a word and if the achievement of the inevitable genuine words through abundant studies, so that the words are like a soft wax; thereby someone who wants to reach the summit of art and sketch, he/she shall develop to overcome challenges in this path through continuous and abundant designing practice, which is similar to constant breathing, daily meals, constant blood flow in veins [23].

William Kirby Lockard writes in his book "Design drawing experiences, c2000":

"During my teaching experience, I have recognized that most students have strong plot mapping background and understand the technical processes of the perspective and shadowing. Although when they add the materials, figures, furniture, landscape in the perspective design, they become disappointed and avoid to draw the perspective."

The proposed approach of this challenge is as follows,

"By such mindset I have reversed any direct order already presented as the freehand perspectives. Now the students learn how to add the final shields. When they learn how to shadow the perspective, the perspective is projected, so that they achieve sufficient skills for adding the surrounding and their eventual design pride and pleasure." [24]

Kate White has the long experience of teaching in the art school and the author of "101 Things to Learn in Art School" in which she notes many specific things for better learning via the art images of the superior artists, so some of her experiences could be mentioned here,

- Design is the first and most important means of expression,

- Projection makes a good idea valuable,

- Design like a great designer in small designs and projects and respect your work,

- Keep a design book or notebook,

- Learn from your peers,

- Architecture is learnt through mind as much as the feelings,

- Space has social and cultural aspects,

- Projection and presentation are a kind of process, which play their role at the moment,

- Studio is not only a workplace, but it is also a mind status,

- Learn to accept criticism,

- Praise the past great protagonists, yet do not repeat anything that has been discovered before, [25].

\section{Conclusion}

In the present article, the effort is made to include a general overview on the useful teaching methods of Architectural Design Basics for the trainers and teachers of these courses. Hereby among the teaching methods, some teaching methods are considered: Professorstudent teaching method, Practical representation of practical exercises, Visiting a real scene, Project based Approach, PeerLearning Method, Discovery method, Designing studio teaching method, Scientific 
representation, Didactic media technology, Freehand design teaching method, and Teaching with competence approach, which are used more than the other teaching methods in the Architectural Design Basics. Though it would not mean that the other teaching methods are not effective in the architecture field, thus if we apply and combine these methods with the other teaching methods in better overlapping, we can reduce the disadvantages and provide the students a better motivation in the middle of the course.

\section{Final approaches}

- Chief directives on the basic courses are self-confidence, spatial visualization, expression skills, boosting creativity, and boosting imagination, which should be explained for the students before the beginning of teaching,

- Skills are learnt through abundant practices, therefore the students should be motivated to perform more practices as much as possible and never neglect the feedbacks,

- Visiting the buildings and monuments in native architecture for freehand mapping, which is a turning point for the preservation of the values of the native architecture, as currently such preservations are inadequate in our city,

- Talking about the works and projects is neglected at Master Study Grade, while the main objective of the course is understanding and expressing the same environment. In the works, we express what is heard, talked, defended, and proven subject to the belief,

- Suggestions for great architecture teachers in Iran: Take a film of your etude use manner and all of the building design phases, so that your manner would be a solution for the beginner designers and thus let all become familiar with the great Iranian architects.

\section{References}

General specifications, schedule, and syllabus in the level of Bachelor of Architecture, Art group (1998), Ministry of Culture and Higher Education, Higher Planning Council, 365th meeting of Planning Council (15/11/1998)

Dehghani Astarki, Mehdi (2011), "Freehand Drawing Training for the first year architecture students, why the training and how the training should be?" the articles of the fourth architecture training conference, University of Tehran, Art Campus, author: Seyed Amir Saeid Mahmoudi.

Kowsari, Nasser (2014), Pedagogy according to the latest standard of the National Technical and Vocational Education Organization, Fourth Edition, Tehran, Etehad-Payame Fan.

Molanaei, Salah Al-Din; Shayan, Sahib (2014), "the influence of pedagogy on education content and objectives and its relationship with inefficiency of new architecture training institutes in Iran", the articles of the fifth architecture training conference, University of Tehran, Art Campus, author: Seyed Amir SaeidMahmoudi.

Arad, Shahrzad (2010), "Evaluation of exploration training impact in the architecture training system of the universities in Iran", the articles of the fifth architecture training conference, University of Tehran, Art Campus, author: Seyed Amir Saeid Mahmoudi.

Ghafari, Ali (1998), "Principles and Basics for Educational Design Environments", the renovation organization of the national schools.

Nazarpour, Najva; Vahidi, Taher (2011), "New Teaching Methods and Approaches in Architecture based on New Teaching Models and Theories", the articles of the fourth architecture training conference, University of Tehran, Art Campus, author: Seyed Amir Saeid Mahmoudi.

Kar, David, Macher, Fenster et al. (2008), "Advanced Teaching Methods", translated by Hashem Fardanesh, Tehran, Kavir.

Safavi, Amanolah (1999), "All Teaching Methods and Techniques by New Teaching Models", Tehran, Moaser Publications. 
Joyce, Bruce (2010), "Learning Models, Teaching Tools", translated by Mahmoud Mehr Mohammadi, Tehran, Samt Publications.

Nadimi, Hamid (2010), "Teacher-Student Method, another perspective", Journal of Honar-Ha-Ye-Ziba Memary Va Shahrsazi (visual arts, architecture, and urban development), No. 44, pp 27-36.

Coach Education and Vocational Research Center (2008), "Teaching Methods and Techniques", Education Science and Supervision Skills Department Associated with Education Organization.

Molanaei, Salahoddin; Soleimani, Sara (2011), "New Architecture Teaching Methods and Techniques based on New Teaching Models and Theories", the articles of the fourth architecture training conference, University of Tehran, Art Campus, author: Seyed Amir Saeid Mahmoudi.

Habibi, Amin (2008), "Learning through teaching others, Assessment of Education System (peer-to-peer)", the articles of the third architecture training conference, University of Tehran, Art Campus, author: Seyed Amir Saeid Mahmoudi.

Farsi Mohammadipour, Alireza; Mehdizadeh Seraj, Fatemeh (2012), "Architecture Design Basic Course Horticulture for Students' Requirements in Architecture Design Courses, Case Study: Entry Students 20042006 in Iran University of Science and Technology", Journal of Honar-Ha-Ye-Ziba Memary Va Shahrsazi (visual arts, architecture, and urban development). Vol. 17, No. 4, pp 61-70.

Sharifan, Ahmad (2012), "Assessment and Evaluation based on Skill Promotion Competence", Vocational Training Journal, Vol. 8, No. 1, pp 46-49.

Daneshgar Moghaddam, Golrokh (2011), "Perspectives, Features, and Domain of Design Issue in Architecture Process", the articles of the fourth architecture training conference, University of Tehran, Art Campus, author: Seyed Amir Saeid Mahmoudi.
Miller, W.R., Miller, Marie (2008), "Academic Lecturing Guide", translated by Vida Miri, Tehran, Samt.

Trainer Instruction Center, Karaj, Iran (2014), Workshop "An Introduction on Training based on Competence and Professional National Framework", 8 May.

Sharifan, Ahmad (2012), "Assessment and Evaluation based on Skill Promotion Competence", Vocational Training Journal, Vol. 8, No. 2, pp 57-58.

Hojat, Ease (2014), "Four Principles of Architecture Training, Outlook on pros and cons of architecture training in Iran", the articles of the fifth architecture training conference, University of Tehran, Art Campus, author: Seyed Amir Saeid Mahmoudi.

Hamidi, Bahram; Rashvandeh, Zeinab (2011), "Sustainable Values of Basic Art Concepts in Visual Arts Training in Higher Education Institutions", the articles of the first national art conference, art college, and author: Mohsen Chinehkesh.

Azari, Omid (2006), "Sketch and Rando Training", Sixth Edition, Tehran, Yassavoli.

William Kirby Lockard (2000), "Design Drawing Skills", translated by Hassan Sajadzadeh, Faezeh Taheri Sarmad, Isfahan, Khak.

White, Kate (2013), "101 Things to Learn in Art School", translated by Parand Taheri, Tehran, Varash.

Molenda, M., 2010, Cone of Experience, Accessed in September 2010, Availableat:http://www.indiana.edu/ molpag e/Cone\%20of\%20Experience_text.pdf,.

Ramaswamy, Sheri, Hene Harris, and UlrikeTschirner. 2001. Student peer teaching: aninnovative approach to instruction in science and engineering education. Journal of Science Education and Technology 10 (2): 165-171.

Durling, Rich, and Connie Schick. 1976. Concept attainment by pairs and individuals as a function of vocalization. Journal of Educational Psychology 68 (1):83-91. 